\title{
Multifunctionality and Aid to Agriculture: A Local Vision of the Banana Sector in the Canary Islands, Spain*
}

La multifuncionalidad y las ayudas a la agricultura: una visión local del sector platanero en las islas canarias, España

\section{La multifonctionnalité et l'aide à l'agriculture: une vision local du secteur de la banane dans les îles Canaries, Espagne}

\section{Pablo Vidueira**, José M. Díaz-Puente***, Miriam López-González****, Delphine Leconte-Demarsy ${ }^{* * * * *}$}

Submitted: 2014-03-10 // Accepted: 2014-07-18// Available online: 2015-01-30

How to cite this article: Vidueira, P., Díaz-Puente, J. M., López-González, M., \& Leconte-Demarsy, D. (2015). Multifunctionality and Aid to Agriculture: A Local Vision of the Banana Sector in the Canary Islands, Spain. Ambiente y Desarrollo, 19(36), xxx-xxx. http://dx.doi.org/10.11144/ Javeriana.ayd19-36.maal doi:10.11144/Javeriana.ayd19-36.maal

\begin{abstract}
Multifunctionality of agriculture is considered a legitimate objective of agricultural policies. Nevertheless, the debate to establish the best way to promote these functions as a whole is still open. This paper analyzes the legitimacy of European aid to agriculture from a local perspective, and under the argument of multifunctionality. To this end, the banana sector of the Canary Islands was selected as a case study, where a participatory study was conducted with all of the agents involved. The results show that European aid to this sector contributes to the achievement of social and environmental objectives. However, it was revealed that the aid should make a more concentrated effort to attain modernization and differentiation of local productive quality, and to promote competitiveness.
\end{abstract}

Keywords: multifunctionality, agricultural policy, international trade, local perspective, banana sector, Canary Islands

Case Study: Evaluation of measures carried out for the outermost regions (Posei), and the smaller islands of the Aegean Sea within the context of the Common Agricultural Policy. European Commission, Evaluation Unit of DG VI. Code: AGRI-2008-EVAL-05

** Msc. Researcher at Universidad Politécnica de Madrid. E-mail: pablo.vidueira@upm.es

*** PhD. Assistant Professor at Universidad Politécnica de Madrid. E-mail: jm.diazpuente@upm.es

**** MSc. Researcher at Universidad Politécnica de Madrid. E-mail: miriam.lopez@upm.es

***** Ingeniero Agrónomo. Fertilizer-Product Manager at Groupe InVivo, París, Francia. E-mail: delphine. leconte@gmail.com 


\section{Resumen}

La multifuncionalidad en la agricultura es considerada un objetivo legítimo de las políticas agrarias. No obstante, el debate para establecer la mejor forma de fomentar estas funciones en conjunto sigue abierto. Este artículo analiza la legitimidad de ayudas europeas a la agricultura desde una perspectiva local y bajo el argumento de la multifuncionalidad. Para este fin se escogió un caso de estudio del sector platanero en las Islas Canarias donde se realizó un estudio participativo con todos los agentes implicados. Los resultados muestran que las ayudas europeas al sector contribuyen a la consecución de objetivos sociales y ambientales. Sin embargo, se detecta la necesidad de concentrar mayores esfuerzos en la diferenciación de las producciones por calidad y fomentar la competitividad.

Palabras clave: multifuncionalidad, política agraria, comercio internacional, perspectiva local, sector del plátano, Islas Canarias

\section{Résumé}

La multifonctionnalité de l'agriculture est considérée comme un objectif légitime des politiques agricoles. Toutefois, le débat pour établir la meilleure façon de promouvoir ces fonctions comme un ensemble reste ouverte. Cet article analyse la légitimité de l'aide européenne à l'agriculture avec une perspective locale, basée sur les motifs de la multifonctionnalité. À cette fin, une étude participative du secteur de la banane dans les îles Canaries, qui a réuni toutes les parties prenantes, a été choisi comme étude de cas. Les résultats montrent que l'aide européenne au secteur contribue à la réalisation des objectifs sociaux et environnementaux. Cependant, la nécessité de concentrer plus d'efforts sur la différenciation des productions basées sur la qualité et la promotion de la compétitivité a étais détectée.

Mots-clés: multifonctionnalité, politique agricole, commerce international, perspective locale, secteur de la banane, Îles Canaries 


\section{Introduction}

In the context of growing liberalization of world markets, countries protect and promote their agriculture as a vital strategic sector of their economies (Segrelles, 2007; Dibden \& Cocklin, 2009). To do this, they create import and export policies, or domestic aid programs, as well as arguments to justify these policies, such as the multifunctional character of agriculture. According to the World Trade Organization (што), agriculture has other functions besides producing food and fibers: an environmental function (protection of the environment and preservation of landscape), and a social function (rural employment and food security).

Multifunctionality of agriculture is not a universal concept, in fact, the emphasis given to its aspects depends on countries and organizations (Ollikainen \& Lankoski, 2005). For European institutions the main objective is to preserve dynamic rural environments, especially in isolated areas (Forge, 2000). It was in 1997 when European multifunctional agriculture became the basis for the reform of the Common Agricultural Policy (CAP) (European Community [CE], 1997; Díez \& Trueba, 2007). In this context, the EU commenced negotiations in the Doha Round with the intention of defending public intervention in agriculture, based on its multifunctional character (Dibden et al., 2009). The official version of the $\mathrm{EU}$ is that multifunctional criteria are included in the two pillars of the CAP: aid to agriculture and rural development measures (Moyano \& Garrido, 2007). Moreover, with eco-conditionality introduced in the 2003 Reform (EC, 2003), the CAP started to be conditioned by environmental and landscape conservation, and the production of goods for society as a whole (Díez \& Trueba, 2007).

Even the liberal framework of the Organization for Economic Cooperation and Development (OECD) recognizes the need to integrate the multifunctional character into the process of liberalizing agricultural markets (Álvarez, 2003); however, there is no consensus on the aspects and methods included under this concept. The Cairns Group — formed in 1989 by major farm-product exporting countries and led by Australia - has no doubt that multifunctionality is a legitimate objective of agricultural policies. But the group advocates the use of instruments specifically aimed at providing non-trade benefits (Unceta \& Malagón, 2007), and it attacks any measure that imposes trade barriers or direct subsidies to agricultural production. This stance contrasts with that of other countries, such as the United States, which provides aid to their domestic agriculture, or Japan and Switzerland, which contend that their protectionist policies are needed for food self-sufficiency and security (Haettenschwiler \& Flury, 2008). In other countries, the term "non-trade concerns" is used more often to conserve the special differentiated treatment given by the wTO (Antón et al., 2007).

In the case of Europe, the agricultural model is based on the need to support domestic production to guarantee the provision of positive external effects (Delorme, 2002). But the European stance is receiving criticism. Some European countries, such as the United Kingdom and Sweden, are in favor of suppressing the first pillar of CAP to concentrate efforts on rural development measures, considering them more multifunctional (Morgan et al., 2006). From the outside, the multifunctionality defended by the $\mathrm{EU}$ is considered a subterfuge to continue protecting and subsidizing community agriculture (Segrelles, 2007).

With this international debate going on, many theoretical studies and contributions from numerous authors (Atance, 2007; O'Connor \& Dunne, 2009; Cairol et al., 2009; among others) seek to enrich the international discussions of these topics. Within this debate there is consensus on the idea that multifunctionality has direct effects, mainly at the local level (Wilson, 2009). For this reason it is necessary to contribute to the theoretical debate with empirical studies that allow the multifunctionality concept to take root in concrete agricultural realities that take into account the local conditioning, factors, and actors that affect this activity (Reig, 2006).

The objective of this paper is, then, to contribute to international discussions through the analysis of the legitimacy of $\mathrm{EU}$ aid to agriculture from a local perspective under the argument of multifunctionality. 
The case study method is used to try to fill in certain gaps in the multifunctionality debate: (1) the lack of empirical data that would permit reaching more solid conclusions regarding public intervention and agricultural multifunctionality (OECD, 2003; Delorme, 2002); and (2) the lack of an analysis at the local level, which is important because most public goods, linked to landscape, environment, or the social context, have a local character (Reig, 2007; Cairol et al., 2009).

\section{Case study}

The Canary Islands (Figure 1) are an Autonomous Community comprised of seven islands with a population of more than two million inhabitants (INE, 2009).

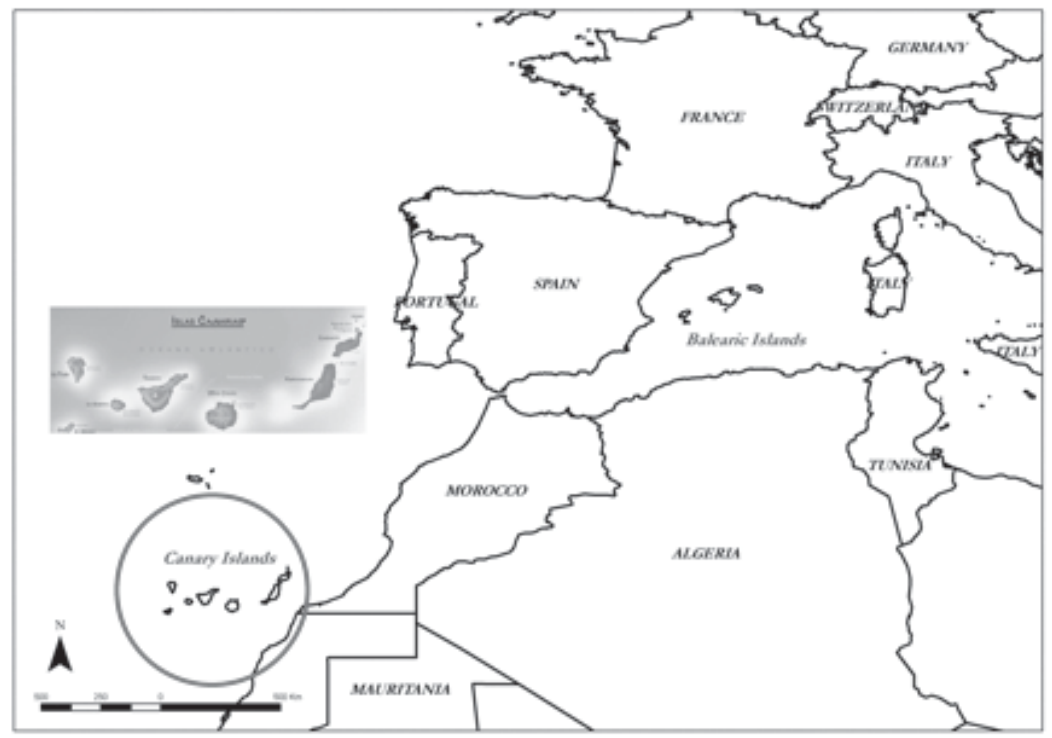

Figure 1. Canary Islands location

Source: Programa de Desarrollo Rural de Canarias 2007-2013 and the authors.

Like other Ultra-Peripheral Regions, the insularity and fragmentation of the Community's territory affect transportation of people and merchandise. The distance from the European continent implicates complicated access to the main centers of production and consumption. Moreover, the same factors have created conditions for broad ecological and cultural diversity, characterized by endemic species, landscapes, and ecosystems recognized universally.

From an economic perspective, the archipelago depends greatly on the continents that surround it. Historically, its economic activities have been centered on export production, but today services account for $75 \%$ of the gross added value; industry (based on agro-food, tobacco production, oil refineries, and energy production) accounts for $8 \%$; and agriculture (although oriented toward export) is only $1 \%$ of the gross added value (Instituto Canario de Estadística, 2011).

$36 \%$ of the arable land (10\% of the territory) is cultivated, $16 \%$ of the population lives in rural municipalities, and $4 \%$ of the employed population works in the agricultural sector (Instituto Canario de Estadística, 2011). Agriculture is a major element of the landscape and the socio-cultural context in many rural zones (Barrera \& Segura, 2008). That is why European aid policies are important for supporting the agricultural sector of the Canaries. These policies are currently grouped in the Programme 
of Options Specific to the Remote and Insular Nature of Canary Islands (Poseican) ${ }^{1}$, which includes major aid to the banana sector.

Mainly produced for export, bananas alone generate $25 \%$ of the annual value of the Canaries' agricultural production (Agencia Canaria de Desarrollo Sostenible y Cambio Climático \& Foro Canario para el Desarrollo Sostenible, 2008), generating incomes of 273.8 million Euros, of which nearly $25 \%$ are aid. Cultivation is essentially irrigated and in open fields that cover $13 \%$ of the total cultivated area. The banana sector generates more than 17,000 jobs, directly or indirectly related to banana production. These jobs are strongly structured in six growers' organizations that are part of the Association of Organizations of Banana Growers of the Canaries (Asprocan). Many challenges arise from competition with other economic actors for natural resources, and the difficulties posed to commercialization by the insufficient transportation and communication infrastructure. Commercialization is made even more difficult by higher costs of production and commercialization than its competitors, such as Ecuador, Costa Rica, or Colombia. In this context, the progressive decreases in duties applied to banana imports from third party countries, and the unilateral negotiations of the EU with some Latin American countries, are seen at the local level as a threat to Canary Island bananas (European Association of Banana Producers [APEB], 2008; Asprocan, 2008).

To face these challenges, the Eu aids the banana sector, and thus, encourages the provision of public goods by maintaining productive activity (Atance, 2007). Since 2006, this has been regulated by Aid I.6 of Poseican, which replaces the former Common Market Organizations (cmo banana), and attempts to adapt to the recent demands of the wTO regarding issues of internal aid to agricultural production. Public goods are generated through a process of joint production. Policies can then act on each concrete public good, or on the private good that the public goods generate. Aid to the banana sector follows an intermediate model: one part involves aid received through смо banana and related to production levels; the other part is designed as an environmental complement per hectare intended to maintain an open field cropping system. The aid covers 8,491 banana growers, who must prove that they produced bananas during the time they received payment. They must also be affiliated with a growers' organization. This aid is funded entirely by the European Agricultural Guarantee Fund, according to Regulation (EC) $n^{\circ} 2013 / 2006$ of the Council. The financial package devoted to this aid is a little more than 140 million Euros a year.

\section{Methodology}

This paper analyzes 2006 to 2009, which is the period during which the new aid format of Poseican was in force. In some cases comparisons are made with data that dates to 2001, a period that was also included in the case study. The study is based on documentary research carried out in Madrid, as well as on participatory field work in the Canaries. The importance and tools used in this case can be found in studies such as Díaz-Puente et al. (2008) or Díaz-Puente et al. (2009).

Both qualitative and quantitative information was collected mainly from official sources - as recommended by Knickel et al. (2009) — such as the European Commission, the National Institute of Statistics, the Ministry of Agriculture, Fishing and Food, The Vice-councils of Agriculture and Livestock of the Government of the Canaries, and ad hoc studies of the Tomillo Center for Economic Studies. During the field work, productive operations were visited and more than 40 people representative of the agricultural and banana sectors were interviewed by telephone or face-to-face through semi-structured interviews.

1 Poseican, for its initials in French, Programme d'Options Spécifiques à l'Éloignement et l'Insularité des les Canaries. This program belongs to Posei (Programme d'Options Spécifiques à l'Éloignement et l'Insularité) and it is implemented through Regulations (CE) no 247/2006 and 793/2006 of the European Council. 
Three models of interview were conducted according to the role of the respondent within the banana sector: the first model, carried out with 10 representatives of the REA (Régimen Específico de Abastecimiento) authorities, 6 representatives of the Mapal (Medidas de apoyo a la producción agraria local) authorities, and 9 representatives of banana associations; the second model, carried out with 9 REA operators; and the third model, carried out with 6 representatives of the banana producers. The collection of primary and secondary data was designed with the purpose of obtaining a triangulation of data (Mikkelsen, 2005).

\section{Results and discussion}

In a location where agricultural production does not seem to be extremely necessary because agricultural products could be imported cheaper from other countries, the risk is that positive externalities could be lost if productive activity is abandoned (Atance, 2007). Three functions associated with agriculture — productive, social and environmental — are analyzed according to recommendations by FAO (2006).

Productive function: food and raw materials. In this sense, the objective of aid is to sustain or develop the agricultural sector. This should be reflected in food security, production levels, maintenance of market quotas, and quality. But the measures that affect production are potentially illegitimate, because they are productivist and market distorters (Reig, 2007). Throughout this section we will discuss whether subsidies to banana production distort trade — and to what extent — so that we can assess whether they can be included in the group of internal aid not subject to reduction, according to the $\mathrm{wTO}^{2}$. The relationship between multifunctionality in the Canaries and in other producer countries should be considered.

Food security. Food security is one of the main non-commercial concerns of agriculture (Antón $e t$ al., 2007; Haettenschwiler \& Flury, 2008; Bjorkhaug \& Richards, 2008). It could be argued, however, that food security depends more on how accessible a private good is for consumers than on the production levels of that product. It follows the idea that it is not necessary to aid agricultural production, but rather to improve the mechanisms for access to the products, in order to improve food security. From the viewpoint of international trade, public regulations on food security may be considered non-tariff barriers (Albisu \& Gracia, 2007) that contribute to world peace (Unceta \& Malagón, 2007). From the European market perspective, food security does not easily serve as an argument to justify aid to banana production because there are alternative products on the market that can be substituted for bananas on a seasonal basis. It is more reasonable for the Canary Islands where the level of self-sufficiency is $15 \%$, contrasting with the $50 \%$ recommended by FAO.

The established channels for the transport of agricultural products have received European aid. It has facilitated the access of Canarian consumers to basic products to a level comparable to the rest of the peninsula. In the case of the banana sector, transport aid has been managed by the banana смо since 1993 and later through Poseican. After the 2006 reform, the crop did not receive aid for transport, which led to negative consequences for banana marketing. This fact directly affected producers, who argued in the interviews that "any alteration in communication with the rest of Spain endangers supply to the archipelago".

Levels of production. An increase in production for domestic consumption and a reduction in dependence on the outside depend on the willingness of Europe to combat abandonment of agriculture (Agencia Canaria de Desarrollo Sostenible y Cambio Climático \& Foro Canario para el Desarrollo Sostenible, 2008).

2 In the што agreement on agriculture, the internal measures not subject to reduction are given in detail, as are the set of measures and policy instruments destined to disappear. 
One way to achieve development of the Ultra-Peripheral Regions of the eu is to diversify production (Behrens \& Gaigné, 2006). But the local authorities and producers feel that alternatives to banana production are scarce. Because of structural (soil-climate conditions required for banana cultivation) or social (age of the growers that restricts taking initiative) limitations, less than $10 \%$ of the banana growers practice multi-cropping. The measures to support banana production, then, become indispensable for maintaining productive levels of the agricultural sector of the Canaries. Aid is still partially linked to productive activity, and the growers must achieve at least $70 \%$ of their reference levels of production to be eligible for receiving the total amount of aid. According to the Government of the Canaries, banana production has yielded a mean of 400,000 tons a year since 2001 (Table 1).

Table 1.

Canarian banana crop yield 2001-2010

\begin{tabular}{cccc}
\hline Year & Production (Tn) & Surface (ha) & Yield (kg/ha) \\
\hline 2001 & 421,820 & 9,194 & 45,880 \\
\hline 2002 & 408,631 & 9,614 & 42,504 \\
\hline 2003 & 401,989 & 9,641 & 41,696 \\
\hline 2004 & 417,968 & 9,710 & 43,045 \\
\hline 2005 & 345,003 & 9,548 & 36,134 \\
\hline 2006 & 348,216 & 9,579 & 36,352 \\
\hline 2007 & 357,813 & 9,563 & 37,416 \\
\hline 2008 & 371,106 & 9,113 & 40,723 \\
\hline 2009 & 352,398 & 9,110 & 38,683 \\
\hline 2010 & 396,508 & 9,112 & 43,515
\end{tabular}

Source: Ministry of Agriculture, Livestock, Fisheries and Water, 2011.

Growers and authorities blame the decrease in 2005 on unfavorable climatic conditions and on strategies aimed at changing varieties. But the same actors agree that under the auspices of Poseican, "aid has permitted them to sustain production and that production would fall without it". According to them, "if there were no subsidies, farms would be abandoned due to the aging population and the retention capacity of staff of the tourism sector, which represents the main economic engine in the islands". Authorities also claim that, "under these agricultural activities, there is a great social network that would be affected negatively if there were no subsidies for local production". In this way, the aid satisfies the requisite of minimum distortion of production, since it does not seek to increase it, but only to maintain its level.

Commercialization. $80 \%$ percent of the bananas consumed in Spain are from the Canaries. The remaining $20 \%$ of the Spanish market is supplied mainly by extra-Community bananas from Ecuador, Costa Rica, Colombia, Cameroon, and the Ivory Coast. Between $75 \%$ and $95 \%$ of the annual banana production of the Canaries is sent to the Iberian market, while the rest is consumed domestically (table 2). The low volume of banana exports to third countries makes it insignificant.

Table 2

Canarian banana production and distribution 2001-2010

\begin{tabular}{cccccc}
\hline Year & Production $(\mathrm{Tn})$ & Shipment $(\mathrm{Tn})$ & $\%$ & Local consumption $($ Tn $)$ & $\%$ \\
\hline 2001 & 421,820 & 388,852 & 92 & 32,968 & 8 \\
\hline 2002 & 408,631 & 374,804 & 92 & 33,827 & 8 \\
\hline 2003 & 401,989 & 368,972 & 92 & 33,017 & 8 \\
\hline
\end{tabular}




\begin{tabular}{cccccc}
\hline Year & Production $(\mathrm{Tn})$ & Shipment $(\mathrm{Tn})$ & $\%$ & Local consumption $(\mathrm{Tn})$ & $\%$ \\
\hline 2004 & 417,968 & 383,586 & 92 & 34,382 & 8 \\
\hline 2005 & 345,003 & 315,548 & 91 & 29,455 & 9 \\
\hline 2006 & 348,216 & 318,186 & 91 & 30,030 & 9 \\
\hline 2007 & 357,813 & 326,558 & 91 & 31,255 & 9 \\
\hline 2008 & 371,106 & 338,655 & 91 & 32,451 & 9 \\
\hline 2009 & 352,398 & 318,793 & 90 & 33,604 & 10 \\
\hline 2010 & 396,508 & 357,154 & 90 & 39,374 & 10 \\
\hline
\end{tabular}

Source: Ministry of Agriculture, Livestock, Fisheries and Water, 2011

Official sources (Ministry of Agriculture, Fisheries and Food of Spain [MAPA], 2003) declare that quotas have not varied since 2001. Even so, interviewees showed great concern about the possibility of losing market quotas, which according to representatives of Asprocan "may decrease $20 \%$ in the next few years". Among Spanish consumers — who traditionally prefer Canary bananas - there is a notable difference between the intention to buy and the final decision, which depends largely on the difference in price between Canary bananas and those from outside of the Eu (Albisu \& Gracia, 2007). Canary Island bananas are more expensive but, as long as their price stays below a maximum threshold $(2 € / \mathrm{kg})$ or the price of bananas stays above a minimum threshold $(0.60 € / \mathrm{kg})$, the sector should not fear loss of market quotas. Critical thresholds were provided by a study carried out by Asprocan. The evolution of banana producer prices (table 3 ) provided by Asprocan is showed in the following table:

Table 3.

Evolution of producer prices 2001-2008

\begin{tabular}{ccccccccc}
\hline Year & 2001 & 2002 & 2003 & 2004 & 2005 & 2006 & 2007 & 2008 \\
\hline $\begin{array}{c}\text { Canarian banana } \\
\text { (euro/Tn) }\end{array}$ & 236.7 & 273.8 & 299.8 & 276.7 & 556.5 & 437.5 & 449.0 & 468.4 \\
\hline
\end{tabular}

Source: Asprocan.

Thus, an important role of aid to banana production is to limit this trend and prevent losing market quotas. It could be a criticism that aid distorts trade flows by influencing prices. But it could also be said that aid is a response that corrects previous distortions in trade flows caused by the tariff reductions forced by the што. In this sense, aid to banana production could be included in the "green box" and be considered legitimate for the wто because of its minimal effects on production and trade flows. Another criticism might be that the aid goes to a sector that is not very competitive in a scenario where tariffs have been progressively lowered. The argument to this criticism is usually that it would be unfair to allow trade reforms because they would allow greater market penetration of countries that are more lax in the application of labor and environmental norms and therefore, have lower costs of production. From this point of view, it would be more correct to establish penalizations on imports from countries that do not comply with the standards of a target market. Such penalizations would pressure exporters into raising their standards to match or come closer to the standards of the countries where they wish to export.

Quality. Another underlying argument in the debate over multifunctionality is the existence of a social demand in favor of agriculture that generates a series of non-commercial goods and services. This is closely linked to promotion of policies regarding quality that favor strategic segmentation of the markets (Albisu \& Gracia, 2007). In Spain, consumers are willing to pay much higher prices for a product that incorporates non-commercial goods and services (Kallas et al., 2007). From the survey, it is concluded that the Canary Island banana sector openly places its stakes on the quality of its produce as a key factor of differentiation with respect to bananas from third countries. Indeed, the interviewees 
assert that "quality has increased in the last five years". This is due to increasingly strict regulations on the use of agro-chemicals and to the growers' efforts to obtain additional certification of quality to more easily position their product on the market (Dankers \& Liu, 2003). Asprocan representatives maintain that "aid has had a part in this increase in quality".

In Europe there is growing consensus on the possibility of encouraging quality production in the EU through Denominations of Origin (DO). Europe defends this posture before the wTO as a form of intellectual property that favors producers of quality food possessing characteristics associated with their geographic origin (Josling, 2006). In the middle of the debate over this posture, it can be said that this instrument would permit consumers to pay for specified attributes of public interest in a private good; in this case, its origin. In this way, public goods are remunerated by the market, making this a perfect economic solution (Reig et al., 2007). In the case of the Canary banana, the industry has committed to obtaining a Protected Geographical Indication, awarded in 2013, and the implementation of RUP (Ultra-Peripheral Regions) symbol as stipulated in Poseican.

The interviewees indicated that "it would be interesting to take advantage of aid to encourage this differentiation in product quality and, thus, help Canary Island bananas attain a more sound position in the Spanish market". Interviewees argued that "more quality requirements should be demanded" and "growers should be assisted in applying ecological methods of production". For Asprocan, however, ecological production is not seen as feasible because it would result in a price increase that consumers would not pay for a product such as bananas. Besides, Asprocan said that "thanks to assistance it is possible for the producers to invest in traceability through new computing tools and improved labeling”.

Multifunctionality in other banana producing regions. It is legitimate that growers in other countries procure a similar certification, but in case they face more difficulties, then they run the risk of exclusion from international markets (Liu, 2009). The concept "multifunctional interdependencies" thus emerges. According to this concept, implementation of multifunctional instruments in a region can be detrimental to the multifunctionality of agriculture in others (Knickel \& Renting, 2000; Wilson, 2008; Losch, 2004). In this context, multifunctionality is defended by the EU as a "subterfuge to continue protecting and subsidizing Community agriculture" (Segrelles, 2007, p. 90), harming other countries whose economies depend on free trade for their raw materials. In the case of bananas, in keeping with the vision of the Cairns Group, aid forms part of the mechanisms that are least harmful because they are partially removed from production and prices, and they pursue objectives of domestic policy without underrating international cooperation. However, it is doubtful that the Eu has designed this aid to encourage agricultural multifunctionality in countries outside the EU, since this aspect is not reflected in the definition of the aid. In this sense, it would be important for the eu to show interest in maintaining agricultural multifunctionality in other regions of the world.

Social function. Agriculture fulfills an important social and cultural function. From a cultural perspective, agriculture has contributed, through time, to configure a valuable historical heritage of local and regional identities, and to produce landscapes transformed by human action (Reig et al., 2007). Conservation of cultural heritage occurs through the contribution to the survival of customs and traditions, such as typical food and local constructions (Atance, 2007). The contribution of the banana sector to the cultural aspects of the islands is notable (Cogea, 2005). But in this section we will focus more on the social function, in terms of sustaining incomes, employment, viability of the rural economy, discouraging outmigration, and social cohesion.

Sustaining incomes. Interviewed growers declare that "the aid they receive accounts for up to $25 \%$ of their final income". Table 4 shows data contrasting this information. The aid allows them to request loans at a lower risk to invest in their operations and gain competitiveness. Indirect beneficiaries are banks and enterprises that produce agrochemicals and cardboard packaging. Sustaining the income of the growers thus impacts to some extent the local economy as a whole. 
Table 4 .

Association's rents

\begin{tabular}{lccc}
\hline & Aid & Total income & \% aid/total income \\
\hline Association 1 & 180,000 & 455,000 & 39.56 \\
\hline Association 2 & 40,000 & 111,250 & 35.96 \\
\hline Association 3 & 73,400 & 34,400 & 213.37 \\
\hline Association 4 & 400,000 & 625,000 & 64 \\
\hline Association 5 & 25,000 & 68,000 & 36.76 \\
\hline Association 6 & $1,000,000$ & $3,185,000$ & 31.40 \\
\hline
\end{tabular}

Source: Asprocan.

According to the associations interviewees: "aids play an essential role in the maintenance of rent". In addition, $100 \%$ of respondents felt that "without the aid production would be abandoned".

Sustaining farmers' income is one of the most important aspects of the social function of aid. But some authors doubt that a policy that increases agricultural benefits through aid can contribute to improving international competitiveness of production (Atance \& Tió, 2000). The discourse of the Cairns Group is dominated by the importance of competitiveness in viable rural economies (Dibden $e t$ al., 2009), while warning that policies to aid multifunctionality can engender systems that are unable to compete and that need public subsidies to guarantee their survival.

Rural employment. More labor is used in the Canary Island banana plantations than in other types of agricultural production (Florido de la Nuez et al., 2002). The sector calls for the incorporation of young people, both entrepreneurs and laborers. Moreover, at times of economic crisis, such as during the period in which this study was conducted, banana plantations absorb labor freed from the most fragile economic sectors. Out of the more than 17,000 jobs the sector generates, more than 2,000 are in related sectors, such as commercial fertilizers and agrochemicals or transport of the product to Spain (González de Cossío, 2008). European aid helps to sustain agrarian structures and areas of production. In doing so, it has an important role in maintaining rural employment.

But some authors question whether rural employment is a non-commercial good, arguing that it is, on the contrary, an input of the productive process (Antón et al., 2007; Reig et al., 2007). The benefits of rural employment would be included in the market value of the good produced. It would not be necessary to remunerate it through aid.

Population stability. The phenomenon of abandonment of farmlands due to unprofitability is extensive in Spain, with the consequent negative social and environmental effects (Kallas et al., 2007). In the Canaries, the banana sector has a major effect on discouraging outmigration from the rural zones (González de Cossío, 2008). The surveyed growers stated that "they also employ family labor which contributes directly to linking families to the countryside" and to a certain degree of "population stability". This can be seen as a positive externality associated with rural employment. Employment in the sector, combined with activities such as rural tourism, is contributing to relieving pressure on territories that are suffering from unsustainable touristic development (Agencia Canaria de Desarrollo Sostenible y Cambio Climático \& Foro Canario para el Desarrollo Sostenible, 2008). Moreover, society might consider it important to maintain certain levels of territorial occupation because it contributes to the reduction of the costs of rural infrastructures per inhabitant.

On the other hand, it might be considered that the changes in spatial distribution of the labor force work through the labor market occur in response to changes in prices and salaries. In this way, it would not be an externality with the character of a public good because it has its own market. Consequently, agriculture's contribution to rural vitality loses importance (Reig, 2007). However, leaving the rural 
population to the mercy of market mechanisms can lead to situations such as those found in Australia, where rural population is clearly declining and several rural regions have become unviable (Alston, 2004). This aspect of multifunctionality is now receiving the attention of Australian academics and politicians (Dibden et al., 2009).

Social structuring. Social structuring in rural areas can also be promoted through policies that have a positive influence in structuring productive sectors. In this sense, aid to banana production contributes to sustaining the structure of the sector in the Canary Islands, which began under the wто banana regime. This explains why the Government of the Canaries, responsible for designing the aid, requires that growers become members of an organization to be able to receive aid. In this way, aid has achieved affiliation with an organization of $100 \%$ of Canary Island banana growers. Table 5 shows the evolution of producer organizations in recent years.

Table 5.

Evolution of producer organizations and organizations groups 2001-2010.

\begin{tabular}{lccccccccccc}
\hline & \multicolumn{1}{c}{$O C M$} & \multicolumn{1}{c}{ Poseican } \\
\cline { 2 - 11 } & 2001 & 2002 & 2003 & 2004 & 2005 & 2006 & 2007 & 2008 & 2009 & 2010 \\
\hline $\begin{array}{l}\text { Producer } \\
\text { organizations }\end{array}$ & 24 & 24 & 6 & 6 & 6 & 6 & 6 & 6 & 6 & 6 \\
\hline $\begin{array}{l}\text { Organizations } \\
\text { groups }\end{array}$ & 1 & 1 & 1 & 1 & 1 & 1 & 1 & 1 & 1 & 1 \\
\hline
\end{tabular}

Source: Asprocan.

The reasons for affiliation are similar in all cases: "looking for a market access", "technical assistance to credit", and "to get more stable or higher price" are the most popular.

It was concluded from the interviews that the European Commission should not leave the decision of whether or not to require affiliation with an organization to the Member States, because promoting structuring of the productive sectors is a multifunctional priority.

Environmental function. Aside from its economic and social importance, Canary Island agriculture plays a fundamental role in the conservation of the environment and of elements of the landscape (Agencia Canaria de Desarrollo Sostenible y Cambio Climático \& Foro Canario para el Desarrollo Sostenible, 2008). The environmental function is implicit throughout Posei as a horizontal value; however many of the interviewees think that "it should have been included explicitly" since the incorporation of multifunctionality as an objective of European policy requires specification of these objectives for each of the functions of agriculture (Atance, 2007). The environmental function is the one over which there is more consensus in international discussions on multifunctionality. In the following sections we will analyze the environmental function as it relates to biodiversity conservation, resource management, and landscape preservation.

Conservation of biodiversity. The credibility of the multifunctionality concept depends especially on the measures adopted to conserve biodiversity (Oñate, 2007). Abandonment of land leads unavoidably to the reduction of biodiversity (Fish et al., 2006). Thus, in Australia, the leader of the Cairns Group tended to abandon extreme neoliberal positions when the catastrophic effects of agriculture on rural ecosystems became noticeable (Dibden et al., 2009). Although Australia tries to move away from European postures, there is consensus on the use of some instruments to conserve biodiversity, including those that encourage growers to show respectful behavior toward the environment and those that encourage their role as direct providers of ecosystem services (Higgins et al., 2007).

In the case of the Canary Islands, biodiversity is one of its greatest riches (Agencia Canaria de Desarrollo Sostenible y Cambio Climático \& Foro Canario para el Desarrollo Sostenible, 2008). Abandoning traditional banana cultivation would implicate loss of food and habitats for wild species (Kallas et al., 
2007). Agro-biological diversity can also be seen as an important aspect, in the sense that mono-cropping should be reduced to favor varied crops in order to promote biodiversity. But it has been seen that, in spite of aid, banana growers do not diversify because viable commercial alternatives are lacking.

The banana organizations consulted mentioned that between $5 \%$ and $10 \%$ of farmers are engaged in other crops, the most common one is tomato. Most producers made attempts to grow other products, but had to abandon because the few alternatives available (avocado, papaya) were not viable. It also emphasizes that the situation varies slightly depending on the islands. Such is the case of Tenerife, which offers a more enabling environment for diversification of their production than the island of La Palma. Therefore, there is not a remarkable diversification of agricultural activity. On the other hand, there are no non-farm alternatives that can participate in conserving biodiversity. Banana production, then, appears to be the only option for sustaining the biodiversity on the Islands.

Resource management. One of the most important aspects of resource management is agricultural soil conservation. Depletion of soils from overuse exacerbates abandonment of the less productive operations and intensifies production in the better plantations. This has negative repercussions on rural areas (Kallas et al., 2007). The Canaries must make an effort to maintain agricultural activity and prevent damage from the erosion, caused by the fallen retaining walls of abandoned crop beds. By maintaining banana production, aid contributes to the conservation of the plant cover and to decrease the negative effects of soil erosion (Kallas et al., 2007).

In the case of the Canaries, banana growers assert that "cultural practices do not pollute and the use of agrochemicals is decreasing". According to them, Poseican involves applying basic rules of respect for the environment; however, they consider self-awareness and implementation of quality standards for its organizations as the principal reasons to improve management in these issues. It is worth a special the certification of the carbon footprint for the Canarian banana received by Asprocan and issued by Aenor (Spanish Association for Standardization and Certification) in 2013. This certifies the accuracy of the calculation of emissions of greenhouse gases in the process of growing, processing, distributing, and maturation of the product. It appears that European legislation and the quality criteria of certification have more influence in this decrease than the aid to banana production.

Local authorities consider banana cultivation in the Canaries as an activity that efficiently uses irrigation water. Usually banana producers employ quite modern production systems and automated irrigation systems. Rain is scarce and irregular, making it necessary that $100 \%$ of the area under banana cultivation is irrigated. Due to the consistent scarcity of water in the archipelago and to the fact that bananas are sold on European markets, the savings on water have always been a key factor in maintaining costs competitive in the face of extra-Community bananas. Moreover, the efficient management of water has favorable repercussions on the environment, reducing lixiviates and the risk of polluting the aquifers. (Ritter et al., 2009)

Preservation of landscapes. Preservation of landscapes is another key ingredient in agricultural multifunctionality, forming part of the most cited criteria in the survey on the demand of public goods linked with agriculture (Sayadi et al., 2009; Gómez-Limón et al., 2007a). There is still no consensus on how to evaluate and assign quantifiable values to the attributes of landscape (Ferrari \& Rambonilaza, 2008). Arguments from Australia and New Zealand contend that at least qualitatively, the untouched natural areas where human activity is negligible are valued more than rural agricultural landscapes (Dibden \& Cocklin, 2009). They claim that the EU uses the defense of agricultural landscapes as a protectionist excuse for maintaining its domestic aid (Dibden et al., 2009). From the European point of view, landscapes created by different crops and agricultural practices give way to visual variations in the created landscape (Kallas et al., 2007). They also feel that it is important to maintain (not increase) production to assure maintenance of the landscape. Moreover, to maintain positive environmental externalities, the grower should receive a compensation that corresponds to the cost of shifting his production from a private optimum to a social optimum (Atance, 2007). 
According to the Government of the Canaries, banana production is vital to maintaining traditional Canary Island landscapes (Agencia Canaria de Desarrollo Sostenible y Cambio Climático $\&$ Foro Canario para el Desarrollo Sostenible, 2008). Pressure from the tourist sector, concerned with maintaining natural landscapes of the islands, is a favorable factor. The part of aid to the banana sector linked to production in open fields becomes relevant because it contributes to covering the costs of field cultivation, which, according to some growers' organizations, is more costly than greenhouse production. The use of greenhouses has been limited by the landscape impact involved. In this sense, aid contributes directly to the preservation of the landscape by maintaining production levels and areas of field production. In addition, both a broader diversity of crops - the mosaic effect - and a higher index of plant cover in irrigated terrain are indicators of landscape improvement in agricultural areas (Gómez-Limón et al., 2007b). Finally, it would be relevant to ask what the true motivation is for maintaining rural landscapes: whether it is more closely linked to economic issues related to tourism or to environmental objectives. It is possible to imagine alternatives for maintaining the landscape that have nothing to do with banana production, that are less costly and possibly as effective, such as the creation of parks containing farm landscapes.

\section{Conclusions}

The present study shows that aid to the banana sector of the Canary Islands contributes to attaining objectives of food security that some countries include within the functions of agriculture. Although this argument is defendable at the level of the Canaries because it is an archipelago removed from the rest of the continent, it would be difficult to apply it to all of the European agricultural zones. In fact, this argument is generally not used by the $\mathrm{EU}$ in the debate over the multifunctional character of agriculture.

The arguments for maintaining levels of banana production and the effect on trade flows are more solid. Aid allows local production to sustain levels that maintain rural employment and viability of rural areas, which contributes to regulating the population balance between rural and urban areas. The possible distortion of trade flows that the Cairns Group criticizes could be interpreted as not being originated from aid, but from the difference in competitiveness between Canary Island production and production outside the EU. In this sense, the debate remains open.

However, the best way to help an agricultural sector should not be by maintaining incomes. This system may discourage competitiveness among the agricultural sectors. In our case study, the local perspective of aid was that it was improving the quality of local production, by contributing to the sector's modernization processes. It was also detected, however, that aid should make more effort in promoting clear differentiation in product quality through more ecological methods of production. It is thus recommendable that aid be proposed as a temporary mechanism to permit modernization and differentiation of local production, and to facilitate adaptation to international trade.

In terms of its social function, this case study showed that maintaining incomes of the local producers has a positive influence on rural employment in general. The cultivation of bananas also contributes to attaining the objective of discouraging outmigration from rural zones. The value of aid in structuring the productive sector at the local level is also considered, the results of which should be promoted by the EU, especially in terms of facilitating organization of the supply and improvement of quality. In addition, the Eu should be interested because this type of agricultural policy objective is not attacked on the international level.

The same conclusion can be reached concerning the lack of explicit mention of the environmental function that banana production fulfils in the Canaries. The eu should specifically include environmental objectives in its aid because there is growing consensus among countries to preserve ecosystems and the local landscapes of the rural zones. As in the Canary Islands, production that has the least relative impact on the environment should be maintained. 
In any case, legitimizing aid in the EU with multifunctional arguments must be accompanied by a clear concern for agricultural multifunctionality in other regions of the world. The defense of multifunctionality of agriculture in one region indirectly implies a loss of multifunctionality in other producing regions of the world. Latin American and African banana-producing countries are those that would be least favored as they confront European aid to their competitors and new trends to improve product quality. To compensate this imbalance, it is important that the governments of those countries also include agricultural multifunctionality in their political objectives. The dialog between the Eu and other countries in agricultural matters should stress exchange of experiences in multifunctionality issues. A multifunctional orientation of agriculture can favor the adoption of appropriate political measures to correct possible market voids and protect the social and environmental functions of agriculture. A more sustainable future can thus be assured for both local and world agriculture.

\section{References}

Agencia Canaria de Desarrollo Sostenible y Cambio Climático \& Foro Canario para el Desarrollo Sostenible (2008). Canarias ante el futuro de las regiones ultraperiféricas en la Unión Europea. Canarias: Agencia Canaria de Desarrollo Sostenible y Cambio Climático.

Albisu, L. \& Gracia, A. (2007). Calidad y seguridad alimentaria: la multifuncionalidad desde el consumidor. In: J.

A. Gómez-Limón \& J. Barreiro (Eds.), La multifuncionalidad de la agricultura en España (pp. 173-188).

Madrid: Eumedia S.A. y Ministerio de Agricultura, Pesca y Alimentación.

Alston, M (2004). You Don't Want to be a Check-out Chick all Your Life': The Out-migration of Young People from Australia’s Small Rural Towns. Australian Journal of Social Issues, 39, 299-313.

Álvarez, A. (2003, febrero). Adaptación de la agricultura española a los criterios de multifuncionalidad. Comunicación en la Jornada Temática sobre la agricultura española en el marco de la PAC, Madrid, Spain.

Antón, J., Compés, R. \& García J. (2007). La multifuncionalidad agraria en el marco del comercio internacional. In: J. A. Gómez-Limón \& J. Barreiro (Eds.), La multifuncionalidad de la agricultura en España (pp. 77-89). Madrid: Eumedia S.A. y Ministerio de Agricultura, Pesca y Alimentación.

Asociación de Productores Europeos de Banano (АРЕв) (2008). Comunicado de la Asociación de Productores Europeos de Banano (APEB). Santa Cruz de Tenerife, Spain.

Asociación de Organizaciones de Productores de Plátanos de Canarias (Asprocan) (2008). La Comisión Europea reflexiona si apelar los acuerdos del plátano. El Deshijado, 2, 3.

Atance, I. \& Tió, C. (2000). La multifuncionalidad de la agricultura: aspectos económicos e implicaciones sobre la política agraria. Estudios Agrosociales y Pesqueros, 189, 29-48.

Atance, I. (2007). Política agraria para una agricultura multifuncional. Un análisis de la PAC reformada frente a la multifuncionalidad. In J. A. Gómez-Limón \& J. Barreiro (Eds.), La multifuncionalidad de la agricultura en España (pp. 91-106). Madrid: Eumedia S.A. y Ministerio de Agricultura, Pesca y Alimentación.

Barrera, B. \& Segura, F. (2008). Impacto de las medidas agrícolas del Posei, 1993-2006. Revista Hacienda Canaria, 24, 99-109.

Behrens, K. \& Gaigné, C. (2006). Developing the "outermost regions" of Europe: some lessons from economic geography. Retrieved on May, 30 2010 from http://agris.fao.org/agris-search/search.do?recordID=FR2014005391

Bjorkhaug, H. \& Richards, C. (2008). Multifunctional Agriculture in Policy and Practice? A Comparative Analysis of Norway and Australia. Journal of Rural Studies, 24, 98-111. 
Cairol, D., Coudel, E., Knickel, K., Caron, P. \& Kroeger, M. (2009). Multifunctionality of Agriculture and Rural Areas as Reflected in Policies: The Importance and Relevance of the Territorial View. Journal of Environmental Policy and Planning, 11, 269-289.

Cogea (2005). Evaluación de la Organización Común de Mercado (OCM) del sector del plátano. Retrieved on May $16^{\text {th }}$, 2010 from, http://ec.europa.eu/agriculture/eval/reports/bananas/ex_sum_es.pdf

Dankers, C. \& Liu, P. (2003). Environmental and Social Standards, Certification and Labelling for Cash Crops. Retrieved on May, 30 2010 from http://www.fao.org/docrep/006/y5136e/y5136e00.htm

Delorme, H. (2002). Ambigüité et richesse de la multifonctionnalité. Comptes rendus des séances de l'Académie d'Agriculture de France, 88, 41-87.

Díaz-Puente, J. M., Yagüe, J. L. \& Afonso, A. (2008). Building Evaluation Capacity in Spain: A Case Study of Rural Development and Empowerment in the European Union. Evaluation Review, 32 (5), 478-506.

Díaz-Puente, J. M., Cazorla, A. \& De Los Ríos, I. (2009). Empowering Communities through Evaluation: Some Lessons from Rural Spain. Community Development Journal, 44 (1), 53-67.

Dibden, J. \& Cocklin, C. (2009). Multifunctionality: Trade Protectionism or a New Way Forward? Environment and Planning A, 41 (1), 163-182.

Dibden, J., Potter, C. \& Cocklin, C. (2009). Contesting the Neoliberal Project for Agriculture: Productivist and Multifunctional Trajectories in the European Union and Australia. Journal of Rural Studies, 25 (3), 299-308.

Díez, E. \& Trueba, D. (2007). Evolución del uso del término multifuncionalidad en el contexto europeo. In J. A.

Gómez-Limón \& J. Barreiro (Eds.), La multifuncionalidad de la agricultura en España (pp. 41-55). Madrid: Eumedia S.A. y Ministerio de Agricultura, Pesca y Alimentación.

European Commission (1997). Agenda 2000. Por una Unión más fuerte y más amplia, COM (97) 2000 final. 15 de Julio, 1997. Brussels: European Commission.

European Commission (2003). Una perspectiva politica a largo plazo para una agricultura sostenible, COM (2003) 23 final. 21 de Enero, 2003. Brussels: European Commission.

European Commission (2006). Reglamento (CE) no 2013/2006 del Consejo, de 19 de diciembre de 2006, por el que se modifican los Reglamentos (CEE) no 404/93, (CE) no 1782/2003 y (CE) no 247/2006 en lo que respecta al sector del plátano. Brussels: European Commission.

Food and Agriculture Organization (FAO) (2006). Roles of Agriculture Project. Retrieved on June, $26^{\text {th }}, 2014$ from http://www.fao.org/economic/esa/esa-resources/esa-projectarchive/esa-roa/en/

Ferrari, S. \& Rambonilaza, M. (2008). Agricultural Multifunctionality Promoting Policies and the Safeguarding of Rural Landscapes: How to Evaluate the link? Landscape Research, 33 (3), 297-309.

Fish, R., Seymour, S. \& Watkings, C. (2006). Suistainable Farmland as Political and Cultural Discourse. Geographical Journal, 172, 183-189.

Florido de la Nuez, C., Aldanondo, A. \& Escauriaza, M. J. (2002). Elasticidad de demanda de importaciones en mercados distorsionados: el mercado francés del plátano. In Ministerio de Industria, Turismo y Comercio (Ed.), Boletín Económico de ICE, no 802209 (pp. 209-224). Madrid: Ministerio de Industria, Turismo y Comercio.

Forge, F. (2000). The Multifunctionality of Agriculture: Summary of the Canadian Federation of Agriculture Conference. Canadá: Science and Technology Division, Government of Canada.

Gómez-Limón, J. A., Kallas, Z. \& Arriaza, M. (2007a). Demanda social de bienes y servicios no comerciales procedentes de sistemas agrarios marginales. In J. A. Gómez-Limón \& J. Barreiro (Eds.), La 
multifuncionalidad de la agricultura en España (pp. 189-206). Madrid: Eumedia S.A. y Ministerio de Agricultura, Pesca y Alimentación.

Gómez-Limón, J. A., Moyano, E., Vera-Toscano, E. \& Garrido, F. (2007b). Actitudes y percepciones sociales sobre la multifuncionalidad agraria: El caso de Andalucía. Revista de Estudios Regionales, 80, 71-101.

González de Cossío, A. (2008). Nueva ayuda al sector de producción de plátano de Canarias. Revista Hacienda Canaria, 24, 129-152.

Häettenschwiler, P. \& Flury, C. (2008). Contribution de l'agriculture à la sécurité de l'approvisionnement. Revue suisse d'agriculture, 40 (2), 69-74.

Higgins, V., Dibden, J. \& Cocklin, C. (2007). Market-Oriented Initiatives for Agri-Environmental Governance: Environmental Management Systems in Australia. In D. Maye, L. Holloway \& M. Kneafsey (Eds.), Alternative Food Geographies: Representation and Practice (pp. 223-240). Oxford: Elsevier.

Instituto Nacional de Estadística (INE) (2009). Series históricas de población desde 1996. Instituto Nacional de estadística. Retrieved on May, 30th, 2012 from: http://www.ine.es/dynt3/inebase/es/index.htm?padre=20\&dh=1

Instituto Canario de Estadística (2011). Canarias en cifras 2011. Retrieved on June, 16th, 2012 from: http://www. gobcan.es/opencms8/export/sites/istac/ galerias/documentos/C00053A/CanariasEnCifras_2011.pdf

Josling, T. (2006). The War on Terroir: Geographical Indications as a Transatlantic Trade Conflict. Journal of Agricultural Economics, 57 (3), 337-363.

Kallas, Z., Gómez-Limón, J. \& Barreiro, J. (2007). Oferta y demanda de bienes y servicios públicos en la agricultura española. In J. A. Gómez-Limón \& J. Barreiro (Eds.), La multifuncionalidad de la agricultura en España (pp. 131-153). Madrid: Eumedia S.A. y Ministerio de Agricultura, Pesca y Alimentación.

Knickel, K. \& Renting, H. (2000). Methodological and Conceptual Issues in the Study of Multifunctionality and Rural Development. Sociologia Ruralis, 40 (4), 512-528.

Knickel, K., Kröger, M., Bruckmeier, K. \& Engwall, Y. (2009). The Challenge of Evaluating Policies for Promoting the Multifunctionality of Agriculture: when 'Good' Questions Cannot Be Addressed Quantitatively and 'Quantitative Answers Are Not that Good'. Journal of Environmental Policy and Planning, 11 (4), 347-367.

Liu, P. (2009). Certification in the Value Chain for Fresh Fruit: the Example of Banana Industry. Retrieved on May $30^{\text {th }}$, 2012 from http://www.fao.org/docrep/012/i0529e/i0529e00.htm

Losch, B. (2004). Debating the Multifunctionality of Agriculture: from Trade Negotiation to Development Policies by the South. Journal of Agrarian Change, 4 (3), 336-360.

Ministry of Agriculture, Fisheries and Food of Spain (MAPA) (2003). Estudio del mercado del plátano en España y Portugal. Gabinete de Estudios de la Comunicación Audiovisual (GECA). Madrid: MAPA.

Mikkelsen, B. (2005). Methods for Development Work and Research. Thousand Oaks: Sage Publications.

Morgan, K., Marsden, T. \& Murdoch, J. (2006). Worlds of Food: Place, Power, and Provenance in the Food Chain. Oxford: Oxford University Press.

Moyano, E. \& Garrido, F. (2007). A propósito de la multifuncionalidad. Discursos y políticas sobre agricultura y desarrollo rural. In J. A. Gómez-Limón \& J. Barreiro (Eds.), La multifuncionalidad de la agricultura en España (pp. 59-75). Madrid: Eumedia S.A. y Ministerio de Agricultura, Pesca y Alimentación.

Organisation for Economic Co-operation and Development (OECD) (2003). Multifonctionnalité, conséquences pour l'action publique. Paris: Organisation for Economic Co-operation and Development. 
O'Connor, D. \& Dunne, W. (2009). Conceptualizing Multifunctionality in the Irish Policy Context. Issues for Policy Formulation, Implementation and Evaluation. Journal of Environmental Policy and Planning, 11 (4), 333-346.

Ollikainen, M. \& Lankoski, J. (2005, Agosto). Multifunctional Agriculture: The Effect of Non-Public Goods on Socially Optimal Policies. $\mathrm{X}^{\text {Ith }}$ International Congress of the EAAE (European Association of Agricultural Economists). Copenhagen, Denmark.

Oñate, J. (2007). Biodiversidad y actividad agraria. In J. A. Gómez-Limón \& J. Barreiro (Eds.), La multifuncionalidad de la agricultura en España (pp. 155-172). Madrid: Eumedia S.A. y Ministerio de Agricultura, Pesca y Alimentación.

Reig, E. (2006). Agricultural Multifunctionality: the State-of-the-art Research Work. European Series on Multifunctionality, 10, 109-147.

Reig, E. (2007). Fundamentos económicos de la multifuncionalidad. In J. A. Gómez-Limón \& J. Barreiro (Eds.), La multifuncionalidad de la agricultura en España (pp. 19-39). Madrid: Eumedia S.A. y Ministerio de Agricultura, Pesca y Alimentación.

Ritter, A., Machín, N. \& Regalado, C. (2009). Evaluación de estrategias para la aplicación de agua en la zona no saturada en el cultivo del plátano. In O. Silva Rojas \& J. Carrera Ramírez (Eds.), Estudios de la Zona no Saturada del Suelo, Vol. IX (pp. 320-327). Barcelona: Cimne.

Sayadi, S., Gonzalez-Roa, M. \& Calatrava-Requena, J. (2009). Public Preferences for Landscape Features: The Case of Agricultural Landscape in Mountainous Mediterranean Areas. Land Use Policy, 26 (2), 334-344.

Segrelles, J. (2007). La multifuncionalidad rural: realidad conflictiva en la Unión Europea, mito en América Latina. Revista Ería, 72, 89-99.

Unceta, K. \& Malagón, E. (2007). La multifuncionalidad agraria y las preocupaciones no comerciales en los debates de la omc. In Ministerio de Industria, Turismo y Comercio (Ed.), Boletín Económico de ICE, no 2920 (pp. 29-40). Madrid: Ministerio de Industria, Turismo y Comercio.

Wilson, G. (2008). Global Multifunctional Agriculture: Transitional Convergence between North and South or Zero-Sum Game? International Journal of Agricultural Sustainability, 6 (1), 3-21.

Wilson, G. (2009). The Spatiality of Multifunctional Agriculture: A Human Geography Perspective. Geoforum, 40, $269-280$. 